\title{
Nuclear Transfer in Ruminants
}

Joon-Hee Lee ${ }^{1,2}$ and Walid E Maalouf ${ }^{3, *}$

${ }^{1}$ Department of Animal Bioscience, College of Agriculture and Life Sciences, Gyeongsang National University, Jinju 600-701, Korea

${ }^{2}$ Institute of Agriculture \& Life Science, College of Agriculture and Life Sciences, Gyeongsang National University, Jinju 660-701, Korea

${ }^{3}$ Faculty of Medicine \& Health Sciences, The University of Nottingham, Nottingham, NG7 2UH, United Kingdom

* Corresponding author:

Walid E Maalouf, BSc, MMedSc, PhD

Tel: 0044-115-82-30699, e-mail: Walid.Maalouf@nottingham.ac.uk

\section{Dedicated to Professor Keith HS Campbell}

"Sheep in Scotland are very, very, very cheap."

Keith HS Campbell, NY Times, 1997.

\section{Summary}

Ruminants were the first mammalian species to be cloned successfully by nuclear transplantation. Those experiments were designed to multiply high merit animals (1-3). Since then, cloning has provided us with a vast amount of knowledge and information on the reprogramming ability of somatic cells to different cell types which became an important basis for stem cell research and human medicine. Nowadays, the goals of most nuclear transfer work vary widely but in most cases the micromanipulation procedures remain the same. However, differences between species require different technical considerations. In this 
chapter, we describe in details somatic cell nuclear transfer which is the foremost methods for cloning ruminants with specific reference to sheep and cattle.

\section{Introduction}

The cloning of ruminants started by the work Steven Willadsen in sheep on electrofusion of embryonic cells with enucleated metaphase two oocytes, which led to the birth of identical lambs (Willadsen, 1986). Similar work by Randall Prather in cattle followed closely (Prather et al., 1987).

In the 1990s, assisted reproduction, genetic engineering, transgenesis, cell biology and other related research were progressing. However, the idea of dedifferentiating a somatic cell into an embryonic state was still science fiction. It was the work of Keith HS Campbell and his colleagues (4-5) that started the revolution and the progress was first marked by the birth of two cloned Welsh mountain ewes - Megan and Morag - from in vitro cultured and differentiated day nine embryo disc cells (5). Then, the breakthrough came about with the birth of Dolly the sheep from cultured somatic mammary cells from a six-year-old pregnant ewe (3). Cloning technology paved the way to a profound understanding of nuclear remodelling and reprogramming and a more thorough knowledge on the mechanisms of early development.

In this chapter, we describe in details somatic cell nuclear transfer which is the foremost methods for cloning ruminants with specific reference to sheep and cattle. 


\section{Materials}

\subsection{Ovary Collection Medium (PBS):}

1. $137 \mathrm{mM}$ Sodium Chloride $(\mathrm{NaCl}), 2.7 \mathrm{mM}$ Potassium Chloride $(\mathrm{KCl}), 10 \mathrm{mM}$ Sodium Phosphate dibasic, $\left(\mathrm{Na}_{2} \mathrm{HPO}_{4}\right)$, and $2 \mathrm{mM}$ Potassium Phosphate Monobasic $\left(\mathrm{KH}_{2} \mathrm{PO}_{4}\right)$.

2. For 1 litre of volume, add $80.0 \mathrm{~g}$ of $\mathrm{NaCl}, 2 \mathrm{~g}$ of $\mathrm{KCl}, 14.4 \mathrm{~g}$ of $\mathrm{Na}_{2} \mathrm{HPO}_{4}$ and $2.4 \mathrm{~g}$ of $\mathrm{KH}_{2} \mathrm{PO}_{4}$, make up to $10.0 \mathrm{~L}$ final volume with distilled water including $\mathrm{pH}$ adjustment to 7.4 with $5 \mathrm{~N}$ Sodium Hydroxide $(\mathrm{NaOH}$, see Note 1).

3. Sterilise by autoclaving for 20 minutes at $15 \mathrm{lb} / \mathrm{in}^{2}$.

\subsection{Oocyte Dissection Medium}

1. For oocyte dissection medium, add $10 \%$ heat-inactivated foetal calf serum (FCS) to Tissue Culture Media 199 (TCM 199). .

2. For $20 \mathrm{ml}$ of volume, add $2.0 \mathrm{ml}$ of foetal calf serum to $18.0 \mathrm{ml}$ of TCM 199 .

3. Sterilise by filtration through a $0.22 \mu \mathrm{m}$ Millipore filter and warm up to a temperature of $39^{\circ} \mathrm{C}$ prior to use. 


\subsection{Oocyte Maturation Medium}

1. Sodium pyruvate stock: add $11 \mathrm{mg}$ of sodium pyruvate to $1 \mathrm{ml}$ of TCM 199 . The sodium pyruvate stock will be diluted in maturation medium to a working concentration of $0.2 \mathrm{mM}$.

2. 17ß-estradiol stock: $1 \mathrm{mg} 17 \beta$-estradiol to $1 \mathrm{ml}$ of Ethyl alcohol. Stock solution can be stored at $-20^{\circ} \mathrm{C}$ for a maximum of one month, and it is diluted in maturation medium to a working concentration of $1 \mu \mathrm{g} / \mathrm{ml}$.

3. Gentamycin stock: add 50mg of gentamycin to $1 \mathrm{ml}$ of normal saline. The stock solution can be stored at $-4^{\circ} \mathrm{C}$, and it is diluted in maturation medium to a working concentration of $50 \mu \mathrm{g} / \mathrm{ml}$.

4. Cysteamine (2- Mercaptoethylamine) stock: add $7.714 \mathrm{mg}$ of cysteamine to $1 \mathrm{ml}$ of TCM 199. The stock solution can be dispensed in $20 \mu 1$ aliquots, and stored at $-20^{\circ} \mathrm{C}$, and it is then diluted in maturation medium to a working concentration of $100 \mu \mathrm{M}$.

5. FSH (Follicular stimulating hormone) stock: add $400.0 \mathrm{mg}$ of FSH (Folltropin®V; Vetrepharm) to $80 \mathrm{ml}$ of normal saline. The stock solution can be dispensed in $20 \mu \mathrm{l}$ aliquots, and stored at $-20^{\circ} \mathrm{C}$. FSH stock will be diluted in maturation medium to a working concentration of $5 \mu \mathrm{g} / \mathrm{ml}$.

6. LH (Luteinizing hormone) stock: add $25.0 \mathrm{mg}$ of FSH (Lutropin®-V; Vetrepharm) to $5.0 \mathrm{ml}$ of normal saline. The stock solution can be dispensed in 20 $\mu \mathrm{l}$ aliquots, and stored at $-20^{\circ} \mathrm{C}$. $\mathrm{LH}$ stock will be diluted in maturation medium to a working concentration of $5 \mu \mathrm{g} / \mathrm{ml}$.

7. Working oocyte maturation medium : add $1 \mathrm{ml} \mathrm{FCS,} 10 \mu \mathrm{FSH}, 10 \mu \mathrm{LH}, 10 \mu \mathrm{l}$ 17ß-estradiol, $30 \mu \mathrm{l}$ sodium pyruvate, and $10 \mu \mathrm{l}$ cysteamine, to $9 \mathrm{ml}$ TCM 199. Sterilise by filtration through a $0.22 \mu \mathrm{m}$ Millipore filter and equilibrate in an 
atmosphere of $5 \% \mathrm{CO}_{2}$ in air with maximum humidity at a temperature of $39^{\circ} \mathrm{C}$ for at least 2 hours prior to use.

\subsection{Composition of Modified Synthetic Oviduct Fluid (mSOF) Medium}

\begin{tabular}{|l|l|l|l|}
\hline Component & MW & Concentration & g/L \\
\hline $\begin{array}{l}\mathrm{NaCl} \\
6\end{array}$ & 58.44 & $107.63 \mathrm{mM}$ & 6.2899 \\
\hline $\mathrm{KCl}$ & 74.55 & $7.16 \mathrm{mM}$ & 0.5338 \\
\hline $\mathrm{KH}_{2} \mathrm{PO}_{4}$ & 136.10 & $1.19 \mathrm{mM}$ & 0.1620 \\
\hline $\mathrm{MgSO}_{4}$ & 120.40 & $1.51 \mathrm{mM}$ & 0.1818 \\
\hline $\mathrm{CaCl}_{2} \cdot 2 \mathrm{H}_{2} \mathrm{O}$ & 147.00 & $1.78 \mathrm{mM}$ & 0.2617 \\
\hline Sodium lactate $(60 \%$ syrup) & 112.10 & $5.35 \mathrm{mM}$ & $757 \mu \mathrm{l}$ \\
\hline NaHCO & & & 0.4200 \\
\hline Na-pyruvate & 84.01 & $5.00 \mathrm{mM}$ & 0.7997 \\
\hline L-Glutamine & 110.00 & $7.27 \mathrm{mM}$ & 0.0292 \\
\hline Tri-Sodium-citrate & 146.10 & $0.20 \mathrm{mM}$ & 0.1000 \\
\hline HEPES & 294.10 & $0.34 \mathrm{mM}$ & 4.7660 \\
\hline Phenol-red & 238.30 & $20.00 \mathrm{mM}$ & $10.0 \mu \mathrm{mg} / \mathrm{ml}$ \\
\hline $\mathrm{H}_{2} \mathrm{O}$ & - & - & $\mathrm{L}$ \\
\hline
\end{tabular}

Adjust osmolarity to 270 to $280 \mathrm{mOsm}$ and to $\mathrm{pH} 7.4$ with $1 \mathrm{~N}$ sodium Hydroxide.

Store at $4^{\circ} \mathrm{C}$ for a maximum of one week.

Before use add $45 \mu \mathrm{l} / \mathrm{ml}$ BME amino acids, 5 $\mu 1 / \mathrm{ml}$ MEM amino acids and 5\% heat inactivated FBS. 
Sterilise by filtration through a $0.22 \mu \mathrm{m}$ Millipore filter and equilibrate in an atmosphere of $5 \% \mathrm{CO} 2$ in air with maximum humidity at a temperature of $39^{\circ} \mathrm{C}$ for at least 2 hours prior to use.

\subsection{Composition of HEPES-Buffered Synthetic Oviduct Fluid (H-SOF) Medium}

\begin{tabular}{|l|l|l|l|}
\hline Component & MW & Concentration & g/L \\
\hline $\mathrm{NaCl}$ & 58.44 & $107.63 \mathrm{mM}$ & 6.2899 \\
\hline $\mathrm{KCl}$ & 74.55 & $7.16 \mathrm{mM}$ & 0.5338 \\
\hline $\mathrm{KH}_{2} \mathrm{PO}_{4}$ & 136.10 & $1.19 \mathrm{mM}$ & 0.1620 \\
\hline $\mathrm{MgSO}_{4}$ & 120.40 & $1.51 \mathrm{mM}$ & 0.1818 \\
\hline $\mathrm{CaCl}_{2} \cdot 2 \mathrm{H}_{2} \mathrm{O}$ & 147.00 & $1.78 \mathrm{mM}$ & 0.2617 \\
\hline Sodium lactate $(60 \%$ syrup $)$ & 112.10 & $5.35 \mathrm{mM}$ & $757 \mu l$ \\
\hline NaHCO & & & \\
\hline Na-pyruvate & 84.01 & $5.00 \mathrm{mM}$ & 0.4200 \\
\hline L-Glutamine & 110.00 & $7.27 \mathrm{mM}$ & 0.7997 \\
\hline Tri-Sodium-citrate & 146.10 & $0.20 \mathrm{mM}$ & 0.0292 \\
\hline HEPES & 294.10 & $0.34 \mathrm{mM}$ & 0.1000 \\
\hline Phenol-red & 238.30 & $20.00 \mathrm{mM}$ & 4.7660 \\
\hline $\mathrm{H}_{2} \mathrm{O}$ & - & $10.0 \mu \mathrm{g} / \mathrm{ml}$ & $10 \mathrm{mg}$ \\
\hline & - & - & $\mathrm{Up} \mathrm{to} 1.0 \mathrm{~L}$ \\
\hline & & & \\
\hline & & & \\
\hline
\end{tabular}

Adjust osmolarity to 270 to $280 \mathrm{mOsm}$ and to $\mathrm{pH} 7.4$ with $1 \mathrm{~N}$ sodium Hydroxide.

Store at $4^{\circ} \mathrm{C}$ for a maximum of two weeks.

Add $5 \mu \mathrm{l} / \mathrm{ml}$ 100X MEM amino acids and $3 \mathrm{mg} / \mathrm{ml}$ BSA before use.

Sterilise by filtration through a $0.22 \mu \mathrm{m}$ Millipore filter

Equilibrate at a temperature of $39^{\circ} \mathrm{C}$ prior to use. 


\subsection{Other Stock Solutions}

1. Hyaluronidase stock (300 IU/mg): add $100 \mathrm{mg}$ hyaluronidase and $1.1 \mathrm{~g}$ PVP to $110.0 \mathrm{ml} \mathrm{Ca}{ }^{2+}-, \mathrm{Mg}^{2+}$-free Dulbecco's phosphate-buffered saline (DPBS). The stock solution can be dispensed in $1 \mathrm{ml}$ aliquots and stored at $-20^{\circ} \mathrm{C}$.

2. Cytochalasin B stock: add $10 \mathrm{mg}$ cytochalasin B to $1.0 \mathrm{ml}$ DMSO. The stock solution can be dispensed in $10 \mu \mathrm{l}$ aliquots, and stored at $-20^{\circ} \mathrm{C}$. Cytochalasin $\mathrm{B}$ stock will be diluted in $\mathrm{H}-\mathrm{SOF}$ at a working dilution of $5 \mu \mathrm{g} / \mathrm{ml}$.

3. Hoechst 33342 stock: add $25 \mathrm{mg}$ hoechst 33342 to $5 \mathrm{ml}$ ddH2O. The stock solution can be dispensed in $10.0 \mu \mathrm{l}$ aliquots, and stored at $-20^{\circ} \mathrm{C}$. Cytochalasin $\mathrm{B}$ stock will be diluted in $\mathrm{H}-\mathrm{SOF}$ at a working dilution of $5 \mu \mathrm{g} / \mathrm{ml}$.

4. $\mathrm{Ca}^{2+}$ Ionophore (A23187) stock: add $5 \mathrm{mg} \mathrm{Ca}^{2+}$ Ionophore (A23187) to $1.91 \mathrm{ml}$ DMSO. The stock solution $(5 \mathrm{mM})$ can be dispensed in $10.0 \mu \mathrm{l}$ aliquots, and stored at $-20^{\circ} \mathrm{C}$. Ca2+ Ionophore (A23187) stock will be diluted in $\mathrm{H}-\mathrm{SOF}$ at a working dilution of $5 \mu \mathrm{M}$.

5. Cycloheximide (CHXM) stock: add $5 \mathrm{mg}$ cycloheximide to $1.0 \mathrm{ml}$ DPBS. The stock solution can be dispensed in $20 \mu \mathrm{l}$ aliquots, and stored at $-20^{\circ} \mathrm{C}$. Cycloheximide (CHXM) stock will be diluted in mSOFaaci at a working dilution of $10 \mu \mathrm{g} / \mathrm{ml}$. 
6. Fusion medium (Mannitol): add $300 \mathrm{mg}$ mannitol, $0.03675 \mathrm{mg} \mathrm{CaCl}_{2} .2 \mathrm{H}_{2} \mathrm{O}$ and $1.1 \mathrm{~g} \mathrm{MgSO}_{4}$, to $110 \mathrm{ml} \mathrm{ddH2O}$. The stock solution can be dispensed in $1 \mathrm{ml}$ aliquots and stored at $-20^{\circ} \mathrm{C}$.

7. Washing medium: supplement $0.1 \%(\mathrm{v} / \mathrm{v})$ penicillin/streptomycin to $\mathrm{Ca}^{2+}-, \mathrm{Mg}^{2+}-$ free Dulbecco's phosphate-buffered saline (DPBS).

8. Isolation medium: supplement $0.25 \%(\mathrm{v} / \mathrm{v})$ trypsin/EGTA to DPBS.

9. Dulbecco's modified Eagle medium (DMEM): supplement 1\% $\beta$-mercaptoethanol, $2 \mathrm{mM}$ L-glutamine, $1.0 \%$ (v:v) penicillin/streptomycin to DMEM.

10. Gelatin solution: add $0.05 \mathrm{~g}$ of gelatin to $50 \mathrm{ml}$ MilliQ water. Autoclave for 30 minutes within 2 hours after mixing. Store the $0.1 \%$ gelatin solution in a refrigerator until use.

\subsection{Preparation of Holding Pipettes for Micromanipulation}

1. Pull borosilicate glass capillaries ( $1 \mathrm{~mm}$ outer diameter (o.d.) x $0.58 \mathrm{~mm}$ inner diameter (i.d.) x $10 \mathrm{~cm}$ without inner filament) by hand over a small flame to give $120-150 \mu \mathrm{m}$ (o.d.).

2. Mark the capillaries and broke at the required size, approximately $150 \mu \mathrm{m}$ (o.d.), using a diamond pencil.

3. Mount the pipette onto the micro forge and heat until the open tip is almost closed, ensuring an internal diameter of approximately $20 \mu \mathrm{m}$.

4. Bend the pipette approximately $2 \mathrm{~mm}$ from the tip at an angle $30-45^{\circ}$, this allowing the tip to be manipulation chamber when mounted on the microscope. 


\subsection{Preparation of Enucleation Pipettes for Micromanipulation}

The preparation of enucleation (or injection) pipettes is more elaborate than the holding pipettes.

1. Pull glass capillaries ( $1 \mathrm{~mm}$ outer diameter (o.d.) $\times 0.58 \mathrm{~mm}$ inner diameter (i.d.) $\mathrm{x} 10 \mathrm{~cm}$ without inner filament) using the flaming micropipette puller to giv e an initial taper, which reduces the diameter of the capillary to slightly greater $\mathrm{t}$ han

the diameter required, with the second taper being almost parallel.

2. Broke a drawn capillary at the required size, between $20-30 \mu \mathrm{m}$ using fine forceps.

3. Mount the pipette in the micro grinder at a $50^{\circ}$ angle and its broken tip ground at medium speed, ensuring a continuous water flow over the surface where the pipette is being ground.

4. Dip the ground angled pipette tip into hydrofluoric acid (see Note 2) for 5 sec whilst continuously blowing air through the capillary using a $10 \mathrm{ml}$ syringe (this prevents acid entering the inside of the pipette), this thins the capillary walls.

5. Wash the pipette washed five times with distilled water to remove the acid and dried. Sigmacote (SL-2) is then drawn into the capillary.

6. Return the pipette to the microforge, the tip of the pipette is touched against a heated glass bead and then pull out to a sharp point.

7. Bend the pipette was bent at an angle of $30-45^{\circ}$ like the holding pipette.

\subsection{Manipulation Chamber}

1. Use a $92 \times 10 \mathrm{~mm}$ petri dish for manipulation chamber. 
2. Place $50 \mu \mathrm{l}$ drops of warmed manipulation medium $\left(39^{\circ} \mathrm{C}\right)$ in the centre of dish and cover in warmed $\left(37^{\circ} \mathrm{C}\right)$ mineral oil, to prevent evaporation of the manipulation medium.

3. Place the chamber onto a heated stage on an inverted microscope fitted with hydraulic micromanipulators for oocyte manipulation.

\section{Methods}

\subsection{Isolation of Primary Foetal Fibroblast Cells}

1. Establish primary foetal fibroblast cultures from a 30-day-old foetus as previously described (6).

2. Dissect the foetus from the uterus and then transport on ice from the slaughterh ouse to the laboratory.

3. Dissect the foetus free of all external membranes, eviscerate and decapitate for isolation of cells from the carcass.

4. Wash the tissue in $\mathrm{Ca}^{2+}-\mathrm{Mg}^{2+}$-free Dulbecco's phosphate-buffered saline (DPBS) at $37^{\circ} \mathrm{C}$, then with alcohol, and finally with washing medium.

5. Cut the tissue into small pieces using sterilise scissors in and incubate at $37^{\circ} \mathrm{C}$ for $5 \mathrm{~min}$.

6. Transfer the suspension into $15 \mathrm{ml}$ centrifugation tubes and allow to sediment.

7. Separate dissociated cells from larger pieces of tissue by centrifugation at 300x G for $5 \mathrm{~min}$.

8. Wash dissociating tissue in DPBS and place it on ice. The procedure is repeated several times.

9. Wash supernatants several times in DPBS, the final supernatant is centrifuged at 
300x $\mathrm{G}$ for $10 \mathrm{~min}$ to obtain a cell pellet.

10. Resuspend the pellet in $10 \mathrm{ml}$ DMEM and $10 \% \mathrm{FCS}$, transfer into $75 \mathrm{~cm}^{2}$ tissue culture flasks and incubate for $24 \mathrm{~h}$ at $37^{\circ} \mathrm{C}$ in a humidified atmosphere of $5 \%$ $\mathrm{CO}_{2}$ in air.

11. Replace the culture medium with fresh medium after $24 \mathrm{hrs}$.

12. Primary cultures are grown on tissue culture plastic coated with $0.1 \%$ gelatin until the first passage in subsequent passages the culture of cells only required $\mathrm{s}$ tandard plastic tissue culture.

\subsection{Passage and cryopreservation of primary foetal fibroblasts}

1. When confluent fibroblast monolayers are obtained, the cells are washed with $2 \mathrm{ml}$ of $\mathrm{Ca}^{2+}-, \mathrm{Mg}^{2+}$-free DPBS $\left(39^{\circ} \mathrm{C}\right)$ twice and incubated in the $0.25 \%$ trypsin/ EGTA solution at $39^{\circ} \mathrm{C}$ for $2-3 \mathrm{~min}$.

2. The solution containing the detached cells is aspirated into a $50 \mathrm{ml}$ conical tube and diluted with $8 \mathrm{ml}$ of DMEM containing 10\% FCS (to inactivate the trypsin). To detach the remaining cells this treatment is repeated three times.

3. The cell suspension is centrifuged at $300 \times \mathrm{G}$ for $5 \mathrm{~min}$ and the cell pellets are resuspended in $30 \mathrm{ml}$ of fresh culture medium.

4. Cells are passaged into $3 \times 75 \mathrm{~cm}^{3}$ flasks and culture continued.

5. At subconfluency, cells are cryopreserved at passage 1 in aliquots of $\sim 1 \times 10^{6}$ per vial. $1 \times 10^{6}$ harvested cells are resuspended in $450 \mu 1$ serum/cryotube $(1 \mathrm{ml}$ tubes), the tubes are placed at $4^{\circ} \mathrm{C}$ for $20 \mathrm{~min}$ and then $10 \%(50 \mu \mathrm{l})$ dimethyl sulfoxide (DMSO) added.

6. The tubes are mixed and immediately stored in polyvinyl bubble wrap at $-80^{\circ} \mathrm{C}$ for 24 hours. 
7. The vials are then transferred to liquid $\mathrm{N}_{2}$ and stored until required.

\subsection{Culture of Cells for Use as Nuclear Donors}

1. For each experiment, a vial of primary fibroblasts is placed in water bath $\left(39^{\circ} \mathrm{C}\right)$ for thawing and cultured in DMEM supplemented with $1 \% \beta$-mercaptoethanol, $2 \mathrm{mM}$ L-glutamine, $1 \%$ (v:v) penicillin/streptomycin and 10\% FCS.

2. Cells are passaged every 3-4 days by trypsin solution $(0.25 \%)$ and plating at split ratio of 1:10.

3. Primary foetal fibroblasts at passages 4-5 are cultured until approximately $80-90$ $\%$ confluence, quiescence (presumptive G0) is then induced by reducing the con centration of FBS to $0.1 \%$ for a further 2-3 days.

4. Immediately before use as nuclear donors, a single cell suspension is prepared by trypsinisation.

5. The cells are and pelleted and resuspended in DMEM plus 0.1\% FBS and remained in this medium at $37^{\circ} \mathrm{C}$ until used as nuclear donors.

\subsection{Oocyte Recovery}

1. Collect ovaries from mature female ruminants at a local slaughterhouse, immedi ately place them into phosphate-buffered saline (PBS) at $25^{\circ} \mathrm{C}$ and transport to the laboratory within 2-3 hours of collection.

2. Trim excess tissue of the ovaries with scissors and wash twice with sterile PBS $\left(37^{\circ} \mathrm{C}\right)$.

3. Aspirate antral follicles ( 2 to $3 \mathrm{~mm}$ diameter) using a $10 \mathrm{ml}$ syringe and a hypodermic needle (21 gauge, $1.5 \mathrm{~mm}$ internal diameter).

4. Transfer aspirated follicular fluid into a $50 \mathrm{ml}$ conical polystyrene tube and 
allow settling for $10 \mathrm{~min}$.

5. Remove three quarters of the supernatant.

6. Dilute the remaining follicular material with an equal volume of dissection medium $\left(39^{\circ} \mathrm{C}\right)$ and transfer it into a $92 \times 10 \mathrm{~mm}$ petri dish.

7. Examine the diluted follicular fluid for oocytes under a dissecting microscope. Oocyte quality is assessed on the basis of morphological appearance.

\subsection{In Vitro Maturation of Ovine Oocytes}

1. Wash selected oocytes three times in dissection medium $\left(20 \mathrm{ml}, 39^{\circ} \mathrm{C}\right)$ and then twice in maturation.

2. For maturation, culture groups of $40-45$ oocytes in $500 \mu \mathrm{l}$ of maturation medium overlaid with mineral oil in 4 -well dishes at $39^{\circ} \mathrm{C}$ in a humidified atmosphere of $5 \% \mathrm{CO}_{2}$.

3. Sterilise dissection and maturation media by filtration through a $0.22 \mu \mathrm{m}$ filter), and equilibrate in an atmosphere of $5 \% \mathrm{CO}_{2}$ in air with maximum humidity at a temperature of $39^{\circ} \mathrm{C}$ for at least 2 hours prior to use.

4. Select only good quality oocytes surrounded by at least three layers of cumulus cells and exhibiting a homogeneous cytoplasm.

\subsection{Oocyte Enucleation}

1. At 15 hours post onset of maturation (hpm), place oocytes into $400 \mu \mathrm{l}$ of $\mathrm{H}$-SOF medium containing $300 \mathrm{IU} / \mathrm{ml}$ of hyaluronidase (type IV) in a $15 \mathrm{ml}$ conical polystyrene tube, incubate at $39^{\circ} \mathrm{C}$ for $2 \mathrm{~min}$ and then vortex for $4-5 \mathrm{~min}$.

2. Wash the denuded oocytes in $\mathrm{H}-\mathrm{SOF}$ medium supplemented with $4 \mathrm{mg} / \mathrm{ml} \mathrm{BSA}$ 
and return to fresh maturation medium.

3. At regular intervals, pre-incubate batches of 15-20 oocytes extruding anaphase/ telophase I (AI-TI) spindle in H-SOF containing $5 \mu \mathrm{g} / \mathrm{ml}$ bisbenzimide (Hoechst 33342 ) for $15 \mathrm{~min}$ at $39^{\circ} \mathrm{C}$ on the heated stage.

4. After incubation, transfer each batch of treated oocytes to manipulation chamber.

5. Using $20 \mathrm{X}$ magnification, pick up and attach a single oocyte to the holding pipette using negative pressure.

6. Change the magnification to $40 \mathrm{X}$ and focus on the oocyte held by the pipette.

7. Bring the enucleation pipette into focus. Using the enucleation pipette, rotate the oocyte into a position where the extruding AI-TI spindle can be aspirated into the pipette (Fig. 1A).

8. Insert the enucleation pipette through the zona pellucida at a point opposite the holding pipette.

9. Manipulate the enucleation pipette into a position next to the extruding AI-TI spindle, apply a small amount of negative pressure, and aspirate the AI-TI spindle from directly beneath it into the pipette (Fig. 1C).

10. Withdraw the enucleation pipette from the oocyte and remove the oocyte from the field of view (see Note 3).

11. Turn off the transmitted light source, change to UV illumination, and examine the aspirated karyoplast (while inside the pipette) for fluorescence using filter block UV-2A. If the metaphase has been removed, it will fluoresce with a blue colour; the spindle will also be visible (Fig. 1B and 1D).

12. Move the enucleated oocyte to the right-hand side of the chamber and discard the aspirated karyoplast from the pipette.

13. Enucleation of oocyte is confirmed by visualization of the DNA in the aspirated 
karyoplast using a short exposure to UV light $(0.1 \mathrm{sec})$.

14. Enucleated oocyte is returned to maturation medium and culture until reconstruction and fusion.

\subsection{Production of Oocyte Cell Couplets}

1. Prepare a manipulation chamber, as for the enucleation procedure, containing H-SOF $4 \mathrm{mg} / \mathrm{ml}$ BSA.

2. Transfer the donor cells into the upper left-hand corner of the chamber and a group of enucleated oocytes into the right hand corner of the chamber.

3. Pick up an encleated oocyte with the holding pipette.

4. Move the holding pipette to the top.

5. Focus the microscope onto the bottom of the chamber.

6. Move the injection pipette to the chamber, manoeuvre it to the cells, and gently aspirate two to three suitable cells into a $25-30 \mu \mathrm{m}$ o.d. pipette (Fig. 1E).

7. Refocus on the enucleated oocyte and move the injection pipette until it is in focus.

8. Insert the injection pipette through the hole previously made in the zona pellucida. While holding the pipette against the cytoplasm, inject a donor cell into the perivitelline space of the oocyte (Fig. 1F).

9. The cell is wedged between the zona pellucida and the cytoplast membrane to facilitate close membrane contact for subsequent fusion (Fig. 1G).

10. Upon completion of each batch (15-20 oocytes), wash and then incubate cytoplast-donor couplets in $\mathrm{H}-\mathrm{SOF}$ without $\mathrm{CB}$ for 10 min until the time of fusion. 


\subsection{Cell Fusion}

1. Cell fusion is carried out at room temperature, in a chamber with two platinum electrodes $200 \mu \mathrm{m}$ apart overlaid with $500 \mu \mathrm{l}$ of fusion medium.

2. Using a hand-drawn capillary mouth pipette, wash two to three couplets in the fusion medium outside the electrodes and then place them between the electrodes

3. Align them with an $\mathrm{AC}$ pulse $(5 \mathrm{~V} / \mathrm{cm}, 5 \mathrm{sec})$ so that the contact surface between the cytoplast and the donor cell is parallel to the electrodes (Fig. 1H, see Note 4).

4. Quiescent primary foetal fibroblasts used as nuclear donors are electrically fused to enucleated cytoplasts with two DC pulses of $1.25 \mathrm{KV} / \mathrm{cm}$ for $30 \mu \mathrm{sec}$ using an Eppendorf Multiporator.

5. After the electrical stimulus, remove the reconstructed embryos from the chamber and gently wash each batch with H-SOF medium.

6. Transfer them into a $50 \mu \mathrm{l}$ drop of $\mathrm{mSOFaaci}$ containing $4 \mathrm{mg} / \mathrm{ml}$ FAF-BSA medium until activation.

7. Pulsed couplets are examined $30 \mathrm{~min}$ after the fusion pulse for fusion.

8. Unfused couplets are re-pulsed once with the above parameters.

\subsection{Chemical Activation}

1. At $1 \mathrm{hr}$ post fusion, activate reconstructed embryos in $\mathrm{H}$-SOF medium plus $5 \mu \mathrm{g}$ $/ \mathrm{ml}$ calcium ionophore (A23187) for $5 \mathrm{~min}$ at $39^{\circ} \mathrm{C}$, followed by culture in mSOFaaci medium supplemented with $10 \mu \mathrm{g} / \mathrm{ml}$ of cycloheximide (CHXM) and $7.5 \mu \mathrm{g} / \mathrm{ml}$ cytochalasin $\mathrm{B}(\mathrm{CB})$ for $5 \mathrm{~h}$ at $39^{\circ} \mathrm{C}$ in a humidified atmosphere of $5 \%$ 
$\mathrm{CO}_{2}$.

\subsection{Culture of Reconstructed Embryos}

1. Following activation, transfer the reconstructed embryos into $50 \mu 1$ drops of mSOFaaci medium containing $4 \mathrm{mg} / \mathrm{ml}$ FAF-BSA covered with mineral oil and culture in a humidified atmosphere of $5 \% \mathrm{O}_{2}, 5 \% \mathrm{CO}_{2}$ and $90 \% \mathrm{~N}_{2}$ at $39^{\circ} \mathrm{C}$.

2. On day 2 of culture, cleavage is assessed and 5\% FBS added to the culture medium.

3. On day 7 , blastocyst stage embryos are surgically transferred into the uterus of synchronized surrogate ewes (see Note 5).

\section{Notes}

1. Dilute solutes in $1 \mathrm{~L}$ of distilled water, adjuct the $\mathrm{pH}$ with $5 \mathrm{~N}$ Sodium Hydroxide, then make up the $10 \mathrm{~L}$ final volume.

2. Hydrofluoric acid is corrosive. It can cause severe burns to the skin and eyes. If it comes into contact with skin, you may not feel pain at once. Hydrofluoric acid is also highly irritating to the respiratory system and very toxic if swallowed. Users should have clear first aid measures in place.

3. Reduce the exposure of enucleated oocytes to the UV light directly to avoid potential long term damage by removing the oocyte from the field of view and observing the enucleated spindle in the aspirated portion inside the enucleation pipette.

4. Precise orientation is necessary for fusion to occur.

5. One to three blastocysts are transferred per recipient. 


\section{Acknowledgements}

The Authors dedicate this book chapter to their late PhD Supervisor, Professor Keith HS Campbell (1954-2012).

This work was partly carried out with the support of "Cooperative Research Program for Agriculture Science \& Technology Development (Project No. PJ009418022013 and PJ009117022013)" Rural Development Administration, Republic of Korea.

\section{References}

1. Willadsen, S.M. (1986) Nuclear transplantation in sheep embryos. Nature 320, 63-65.

2. $\quad$ Prather, R.S., Barnes, F.L., Sims, M.M. et al. (1987) Nuclear transplantation in the bovine embryo: assessment of donor nuclei and recipient oocyte. Biology of reproduction $\mathbf{3 7}, 859-866$.

3. Wilmut, I., Schnieke, A.E., McWhir, J. et al. (1997) Viable offspring derived from fetal and adult mammalian cells. Nature 385, 810-813.

4. Campbell, K.H., Loi, P., Otaegui, P.J. et al. (1996) Cell cycle co-ordination in embryo cloning by nuclear transfer. Reviews of reproduction 1, 40-46.

5. Campbell, K.H., McWhir, J., Ritchie, W.A. et al. (1996) Sheep cloned by nuclear transfer from a cultured cell line. Nature 380, 64-66.

6. Wells, D.N., Misica, P.M., McMillan, W.H. et al. (1998) Production of cloned bovine fetuses following nuclear transfer using cells from a fetal fibroblast cell line. Theriogenology 49, 330-330. 


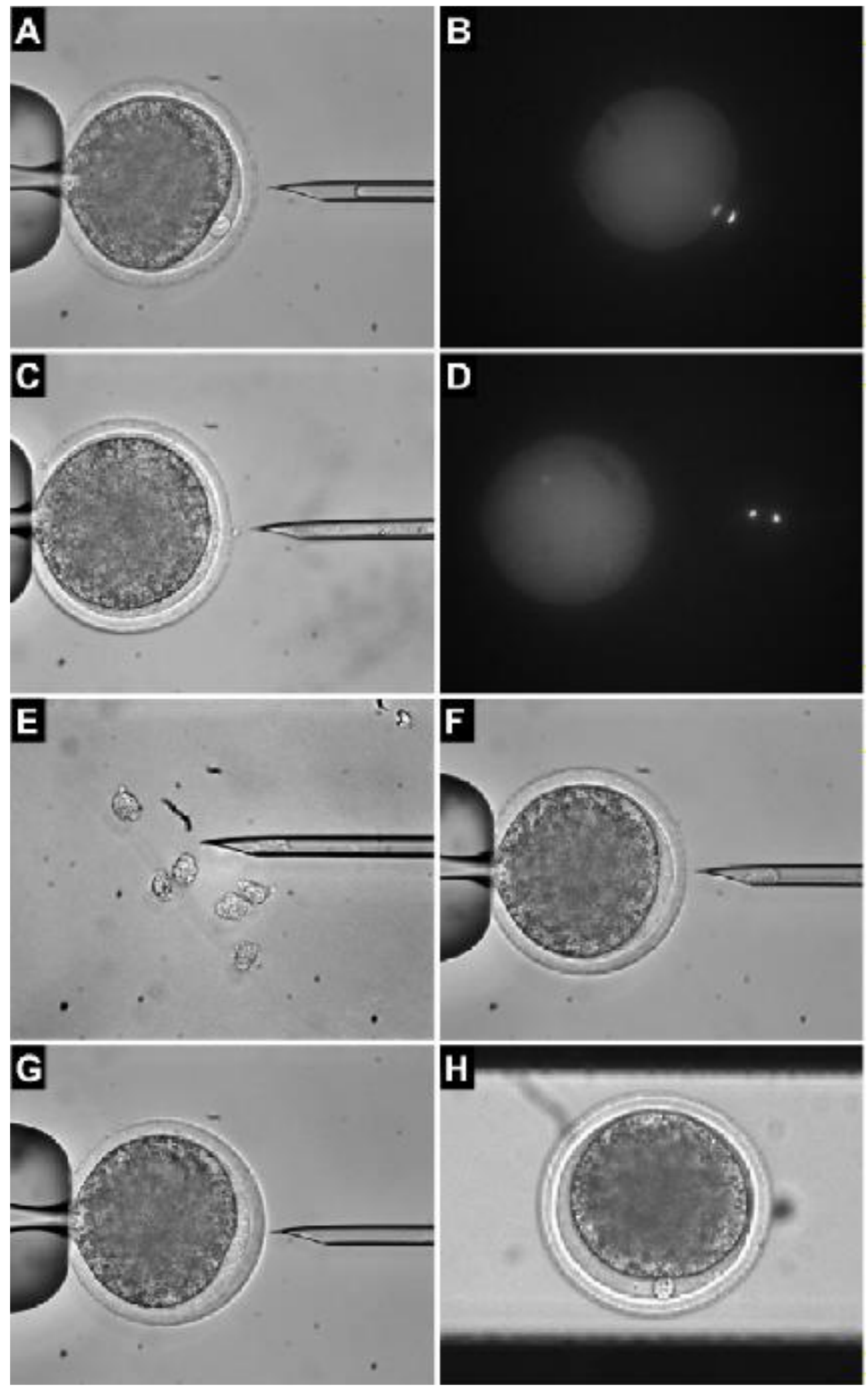

FIGURE 1. Enucleation of ovine oocytes and production of oocyte somatic cell couplets

A: Holding the Anaphase 1- Telophase I (AI-TI) oocyte prior to enucleation (the extruding AI-TI spindle). B: Localization of extruding AI-TI spindle by epifluorescence. C: Enucleated oocytes. D: Confirmed by epifluorescnece (the extruding AI-TI spindle in the pipette). E: Somatic cells in suspension. F: Transfer of donor cell into enucleated oocyte. G: Cells after transfer should be in close contact with the oolema. $\mathbf{H}$ : The couplet is positioned between the electrodes (dark lines) for fusion. 